\title{
ECONOMICS CAPITALISM, THE BIRTH OF STATE AND AL-QURAN RULES
}

\author{
Chairul Iksan Burhanuddin, Burhanuddin \\ Fakultas Ekonomi dan Bisnis, Fakultas Ekonomi \\ Universitas Muhammadiyah Makassar, Universitas Negeri Makassar \\ chairul.iksan@unismuh.ac.id
}

\begin{abstract}
ABSTRAK
Ekonomi kapitalis-sosialis yang telah lama menjadi paradigma dalam kegiatan perekonomian seolah-olah menjadi bumerang dalam paradigma itu sendiri. Melihat kondisi perekonomian yang semakin tidak menentu, membuat orang berfikir untuk mencari solusi atas permasalahan yang terjadi. Mahzab pemikiran Karl Marx dan Adam Smith tidak seindah yang dibayangkan. Konsep monopolistik justru memunculkan isu-isu kesejahteraan manusia dan ketidakseimbangan alam yang tidak lagi dapat bisa di tolerir. Konsep pemikiran ini akhirnya telah sampai pada titik jenuh. Ekonomi Islam atau Ekonomi Syariah sempat menjadi alternatif dalam menanggulangi permasalahan tersebut. Akan tetapi, apakah ekonomi Syariah telah sesuai dengan ketentuan yang ditetapkan oleh Allah SWT dalam Al-Quran? Kembali kepada aturan Syariah, bukan berarti kembali kepada aturan yang ditetapkan oleh Allah SWT. Metode penelitian dilakukan melalui pendekatan kualitatif, dengan menggunakan metode Library Research. Hasil penelitian ini memberikan perspektif ekonomi dengan cara memberikan penjelasan didasarkan ayat-ayat yang terkandung dalam Al-Quran. Mulai dari solusi dalam permasalahan proses produksi dan konsumsi, perdagangan, konsep keseimbangan, serta pengelolaan utang piutang.
\end{abstract}

Kata kunci: kapitalis, sosialis, ekonomi, syariah, muamalah

Abstract

The long-standing socialist capitalist economy is a paradigm in economic activity as if it backfires within the paradigm itself. Looking at increasingly uncertain economic conditions, make people think to find solutions to the problems that occur. The Mahzab thought of Karl Marx and Adam Smith was not as beautiful as imagined. Monopolistic concept is precisely raises human welfare issues and natural imbalance that can no longer be tolerated. This concept of thought has finally reached the saturation point. Islamic economics or Sharia economics had become an alternative in addressing the problem. However, is the sharia economy in accordance with the provisions established by Allah SWT in the Qur'an? Returning to the sharia rule, does not mean to return to the rules established by Allah SWT. The research method is done through a qualitative approach, using the Library Research method. The results of this study provide an economic perspective by providing explanations based on the verses contained in the Qur'an. Starting from solutions in the problems of production and consumption processes, trading, the concept of balance, and debt management of receivables.

Keywords: capitalist, socialist, economics, sharia, Muamalah

\section{PENDAHULUAN}

Latar belakang perekonomian yang dikenal saat ini dibentuk oleh dua pemeran utama, yang pertama adalah mazhab atau pemikiran ekonomi yang lahir dari sejarah itu 
sendiri. Kedua, pemikiran Karl Marx dan Adam Smith yang cenderung berimplikasi pada masalah ekonomi sosialis (Mayer 1975).

Adapun dua aspek utama yang akan dibahas dalam tulisan ini, yaitu: yaitu terkait dengan bagaimana interpretasi kebebasan ekonomi pada saat ini yang dibarengi dengan kebebasan politik yang kaitannya dengan ajaran Islam yang mengatur mengenai perekonomian.

Kita melihat banyak isu-isu sosial yang ditimbulkan oleh kebijakan-kebijakan ekonomi yang dibentuk atas asas kebebasan yang disebut sebagai demokrasi. Contohnya isu pengangguran dan lapangan pekerjaan, belum lagi masalah yang terkait dengan produksi dan konsumsi.

Selain itu selama dua abad terakhir, seperti yang kita ketahui bersama, kapitalisme telah menyebar ke seluruh dunia dan pada saat yang sama, tingkat kebebasan politik telah meningkat juga, walaupun pada kenyataan kebebasan politik akhirnya telah sampai pada titik jenuh (Pryor 2010). Hubungan antara dua kecenderungan ini, pada umumnya, merupakan topik yang relatif tertutup untuk dianalisis lebih mendalam. (Friedman 1962) dalam tulisannya mengemukakan bahwa: "Kebebasan ekonomi (Ecomomics Freedom) juga merupakan sarana yang sangat diperlukan menuju pencapaian kebebasan politik (Political Freedom)".

Hadirnya Islam sebagai pendekatan yang paling relevan kemudian memberikan mahzab pemikiran baru dalam perkembangan ilmu ekonomi adalah mengenai kitab suci (Al-Quran) dan sejarah pada masa-masa pertumbuhan Islam di beberapa belahan dunia. Dalam awal sejarahnya kita mengenal pribadi Nabi Muhammad yang tak lain seorang pedagang, kemudian Nabi Muhammad dan Al-Quran menjadi dua hal yang tidak terpisahkan dalam sejarah (Hefner 2006).

Peradaban Muslim dalam hubungannya dengan perkembangan ekonomi tidak pernah mengembangkan bank atau instrumen perusahaan lainnya yang begitu sentral bagi perkembangan kapitalisme modern di Barat. Instrumen lainnya yang kemudian berkembang dan paling banyak digunakan pada saat ini misalnya perdagangan saham atau efek di Bursa Perdagangan, di Indonesia kita kenal Indonesia Data Exchange (IDX).

Pemikiran Marx telah menimbulkan pembaharuan. Pembaharuan secara ekonomi tersebut dibarengi dengan perubahan tatanan ekonomi yang signifikan. Hal ini berdampak pada berbagai sktor dan juga berpengaruh terhadap lingkungan dan yang lainnya. Alquran kemudian hadir sesebagai sebuah solusi untuk tatanan kehidupan yang lebih seimbang

Dalam tulisan kali ini akan mengemukakan permasalahan yang terkait dengan kapitalisme dan lahirnya Negara kemudian memberikan solusi atas permasalahan tersebut dengan merujuk pada Al-Quran.

\section{METODE PENELITIAN}

Metode Penelitian yang digunakan adalah menggunakan pendekatan kualitatif dengan menerapkan metode riset kepustakaan (Library Research). Riset kepustakaan menggunakan literatur sebagai objek kajian. Data yang digunakan dalam penelitian ini adalah berupa data sekunder, yaitu buku-buku, jurnal-jurnal ilmiah dan informasi lainnya dari internet yang dianggap valid. Sedangkan untuk menjawab permasalahan, penelitian ini akan menggunakan metode content analysis dengan memberikan data-data untuk menjawab permasalahan tersebut. 


\section{HASIL DAN PEMBAHASAN}

\section{A. Ekonomi Kapitalis-Sosialis dan Lahirnya Modernisasi Dalam Perekonomian}

Dalam ekonomi kapitalis dan sosialis, teori yang sudah diketahui bersama adalah mengenai permintaan dan penawaran: menyatakan bahwa semua kegiatan ekonomi yang berjalan secara alami dipengaruhi oleh fluktuasi permintaan (demand) dan penawaran (Supply) pasar (Buchanan 1968).

Kebijakan ekonomi kapitalis dan sosialis dapat digambarkan dalam tabel sebagai berikut:

Tabel 1. Sistem ekonomi sosialis dan Kapitalis (Pack 1991; Vaughn 1989).

\begin{tabular}{|l|l|l|}
\hline No. & \multicolumn{1}{|c|}{ Sistem Ekonomi Sosialis } & \multicolumn{1}{c|}{ Sistem Ekonomi Kapitalis } \\
\hline 1 & Inisiatif dan kreatifitas yang minim & $\begin{array}{l}\text { Individualisme, Hedonisme, dan } \\
\text { Materialisme }\end{array}$ \\
\hline 2 & $\begin{array}{l}\text { Praktik Monopoli oleh pemerintah dan } \\
\text { swasta }\end{array}$ & $\begin{array}{l}\text { Homoeconomicus } \text { (Mengejar } \\
\text { kepentingan dan keuntungan sendiri) }\end{array}$ \\
\hline 3 & $\begin{array}{l}\text { Masyarakat tidak bebas dalam memiliki } \\
\text { sumberdaya yang ada }\end{array}$ & $\begin{array}{l}\text { Perekonomian diatur oleh mekanisme } \\
\text { pasar }\end{array}$ \\
\hline
\end{tabular}

Dalam sistem monopoli, penekanan para pelaku ekonomi adalah pada kontrol pasokan atau harga suatu produk. Produk dalam hal ini didefinisikan dalam hal yang terkait dengan pilihan konsumen. Beberapa kontrol pasar ada ketika penjual dapat meningkatkan atau mengurangi penjualannya, kemudian dapat mempengaruhi harga di mana produknya dijual. Monopoli diidentikkan dengan kontrol pasar, elemen-elemen monopolistik praktis ada di mana-mana. Hal ini tercermin dalam pasar ekonomi bahwasanya siapa yang memiliki modal lebih banyak maka dialah penguasanya (Mason 1937).

Namun di sisi lain, jika ekonomi yang sifatnya monopolistic ingin menempatkan dirinya dalam posisi untuk berkontribusi pada perumusan kebijakan publik, maka harus memahami masalah monopoli dengan cara yang lebih luas daripada kondisi saat ini. Adanya diskriminasi harga, kekakuan harga, pengeluaran iklan, kepemimpinan harga dan praktik-praktik lain sudah cukup untuk menunjukkan adanya elemen monopoli. Tetapi praktik-praktik ini bukanlah bukti yang cukup tentang keberadaan atau kemungkinan kontrol pasar yang merugikan kepentingan umum. Boleh jadi kita bisa melihatnya pada dampak lingkungan yang diakibatkan oleh kebijakan monopoli (Mason 1937:49).

Lebih lanjut jika berbicara mengenai sikap materialistik dan hedon, dapat dijelaskan sebagai bentuk model pemborosan konsumen yang disebabkan oleh keinginan memperoleh sebuah nilai prestise. Efeknya, uang tidak lagi dimaknai sekadar ekonomi; namun memiliki makna sosial yang memungkinkan konsumen untuk saling meniru dalam pilihan dan penggunaan barang-barang konsumen mereka hingga dapat memuaskan hasrat/keinginan dalam mendapatkan suatu barang/jasa (Youn and Doyle 1999).

Melihat paradigma konsumen menggunakan uang sebagai alat kekuasaan kemudian tanpa ragu menggunakan uang tersebut untuk membuat orang terkesan atau terlihat dominan (Goldberg and Lewis 1978). Salah satu cara konsumen menunjukkan kekuatan sosial mereka adalah dengan membeli barang-barang yang sifatnya materil. Pola konsumsi dan akumulasi barang yang sifatnya materialistis memungkinkan mereka 
merasa kuat secara sosial. Sayangnya, pola konsumsi seperti ini adalah proses yang kompetitif dan komparatif yang dapat mengubah pola perilaku manusia (Durvasula and Lysonski 2010). Selain itu sikap materialistik dapat dikonseptualisasikan dalam berbagai bentuk termasuk pengabdian pada kebutuhan dan keinginan materil, hal ini dipandang sebagai suatu pola pikir yang difokuskan pada mendapatkan dan membelanjakan, atau sebagai keterikatan yang dimiliki seseorang untuk memiliki harta duniawi (Richins and Dawson 1992).

Dalam pandangan (Vadillo, 2016) mengemukakan bahwa akar dari lahirnya kapitalisme adalah lahirnya bank-bank di berbagai belahan dunia. Diawali dengan peristiwa dibentuknya bank pertama kali pada tahun 1605 dengan nama Banco de spiritus Sanctus atau Bank Roh Kudus yang ada di Vatikan. Kemudian dilanjutkan dengan dibentuknya Bank of England. Bank of England inilah cikal bakal lahirnya lembaga yang disebut sebagai Negara.

Akibat modernisasi perekonomian yang dilakukan pada masa kolonialisme dari Negara kemudian lahirlah yang disebut sebagai utang negara. Utang negara dimulai ketika Inggris yang hendak berperang melawan Perancis, dimana pada saat itu Inggris kehabisan emas dan perak (harta rampasan) untuk mendanai perang yang akan dilangsungkan. Akhirnya Raja pada waktu itu mendatangi pedagang kaya di London dan banker pandai emas di London untuk memperoleh uang ini. Disitulah awal mula pembentukan sindikat dalam proses penerbitan uang.

(Quigley 1966) menuliskan bahwa bank memperoleh keuntungan dari bunga atas semua uang yang diciptakan dari ketiadaan. Sampai disini, apakah saat ini kita belum sadar dari pernyataan tersebut? Bahwasanya ketiadaan nilai dari uang kertas telah dipertukarkan dengan sesuatu yang memiliki nilai dan wujud yang dapat diukur. Kertas yang hanya dibubuhi nilai dan legalitas yang oleh pemerintah kemudian kita gunakan untuk dipertukarkan dengan barang dan jasa. Hal itulah yang menjadi awal mula pencengkeraman sistem moneter dunia selamat kurun waktu kurang lebih 300 tahun.

Dari sejarah lahirnya Bank of England, maka telah lahir pula tiga unsur penting dalam lembaga yang kita sebut sebagai negara, yaitu Utang Nasional, Uang Fiat dan Bank Sentral. Pertanyaan selanjutnya adalah Bank Indonesia yang kita kenal selama ini sebagai Bank milik Negara Indonesia apakah betul milik Negara?. Jawabannya adalah tidak, jika melihat awal sejarah kemerdekaan Indonesia dalam kaitannya dengan Bank, maka BNI 1946 merupakan Bank Sentral yang dimiliki oleh Indonesia (Vadillo, 2016).

BNI 1946 menerbitkan ORI (Oeang Repoeblik Indonesia) dengan standar emas: setiap Rp. 10 didukung 5 gram emas. Ini artinya, setiap Rp. 1 dijamin 0,5 gram emas. Namun pengakuan kemerdekaan pada saat itu tidak diamini oleh pemerintah kolonial Belanda dengan mengajukan beberapa syarat yang akhirnya dirundingkan dalam Konferensi Meja Bundar (KMB) pada tahun 1949.

Hasil KMB pada saat itu memutuskan bahwa: pertama BNI 1946 harus dihentikan aktivitas operasionalnya dan digantikan dengan Bank Sentral N.V De Javasche, sebuah perusahaan swasta milik beberapa pedagang yahudi belanda yang kemudian dalam sejarah berubah nama menjadi Bank Indonesia. Kedua, ORI digantikan dengan Uang Bank Indonesia yang direalisasikan pada tahun 1952, dan yang ketiga adalah utang pemerintah kolonial Belanda sebesar 4 miliar dolar AS kepada para banker swasta diambil alih oleh Indonesia.

Pada tahun 1965 Presiden Soekarno merasa hasil perundingan tersebut justru membawa dampak yang semakin buruk kepada Indonesia yang kemudian memutuskan 
untuk menolah lebih lama kehadiran IMF dan Bank Dunia di Indonesia. Namun keputusan dari Presiden Soekarno pada saat itu harus di bayar mahal dengan pengasingan yang dilakukan kepadanya pada tahun 1967. Lalu ditandai dengan diangkatnya Jenderal Soeharto sebagai presiden menggantikan Soekarno. Tindakan awal yang dilakukan oleh Soeharto pada tahun 1967 adalah mengundang kembali IMF dan Bank Dunia kemudian menundukkan diri sebagai anggota PBB (Vadillo, 2016).

Seiring perkembangan perekonomian, tidak dapat dipungkiri bahwa yang memaikan peranan penting dalam suatu perekonomian adalah kepemilikan uang. Namun, kita perlu memahami esensi dari uang itu sendiri. Jika kita mengajukan pertanyaan tentang esensi dari uang: maka jawaban yang akan kita temukan adalah sebagai lindung nilai, sekaligus sebagai alat tukar dalam aktivitas manusia. Namun seiring berjalannya waktu uang yang kita kumpulkan tidak akan sama nilainya ketika pertama kali kita dapatkan. Hal ini mungkin disebabkan oleh inflasi atau mungkin deflasi. Sehingga kemampuan dari uang itu sendiri berubah seiring berjalannya waktu. Bisa jadi hari ini kita mampu untuk menggunakan uang Rp.100.000 untuk memenuhi kebutuhan dalam 1 hari namun dilain waktu uang Rp. 100.000 tersebut tidak akan mampu memenuhi kebutuhan 1 hari bahkan nilainya tidak ada sama sekali (Clarke n.d.).

Boleh dikatakan bahwa laju perekenomian memberikan dampak cukup negatif dalam kaitannya dengan kesejahteraan masyarakat. Contohnya dari segi pengangguran, menurut data Badan Pusat Statistik per februari 2020, data pengangguran di Indonesia terdapat kenaikan sejak februari 2019 yaitu dari 6,82 juta orang menjadi 6,88 juta orang atau $1 \%$ hal ini belum dilihat lagi apabila dikaitkan dengan dampak Virus Corona yang hingga mei 2020 sangat menganggu sektor perekonomian. Data pengangguran dapat dilihat dalam tabel sebagai berikut:

Tabel 3. Data pengangguran per Februari 2020 (BPS n.d.):

\begin{tabular}{|c|c|c|c|c|c|c|c|}
\hline 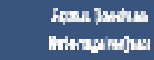 & คrü mo & Giver IIA & hanat sous & hanth & an & rim & 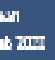 \\
\hline it) & g! & 9 & (n) & 5 & 15 & 가 & 17 \\
\hline & ז & whey & parowh & 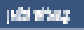 & grom & proming & whing \\
\hline mentisent & ב:1: & LEAt: & $10 \%$ & 2n & $\alpha ! n$ & $i$ & 1.2 \\
\hline "whinste, & sset & ¿\$. 6 & $1 \times 4$ & Lia & 2 & 1..: & A... \\
\hline bi, & $\mid 290$ & Inese & $10 . \mathrm{K}$ & s" & 1,91 & + & $9, \cdots$ \\
\hline 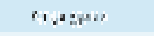 & *x: & $\$:$ & $8 \mathrm{x}$ & wis & $4 \%$ & sin & (i: \\
\hline 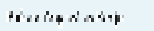 & $x / i^{\prime}$ & $6, x$ & 18.6 & $a$ & 1,1 & 1.t. & $x(1)$ \\
\hline
\end{tabular}

Meningkatnya tingkat pengangguran boleh jadi disebabkan oleh kegagalan sistem ekonomi kapitalis dalam mengatur keberlangsungan hidup masyarakat dan lingkungan. Dalam sistem ekonomi kapitalis yang sifatnya monopolistik dapat memberikan pengaruh negatif, dimana segala sesuatu diukur dari siapa yang lebih kuat dan mampu menguasai pasar. Contoh kasus perihal monopolistik adalah melihat Carrefour sebagai raja retail di Indonesia sementara masyarakat yang tidak memiliki modal, tidak memperoleh kesempatan dalam menjalankan aktivitas perdagangan. Dalam perspektif ini bisa dikatakan yang kuat akan semakin kuat sedangkan yang lemah akan semakin lemah. 


\section{AkMen}

\section{B. Ketentuan dalam Al-Quran dan Muamalah dalam Ajaran Islam}

Perekonomian dalam sejarah Islam telah lama berkembang sebelum masa kejayaan agama Islam. Teori Produksi dan Konsumsi pun telah diajarkan oleh Allah SWT. Seruan terkait proses produksi sebagaimana tertulis dalam Al-Quran surat Al Anbiya (80), sebagai berikut:

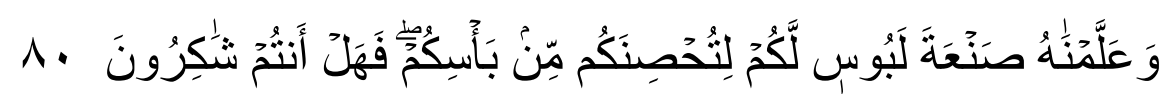

Terjemahnya: Dan telah Kami ajarkan kepada Daud membuat baju besi untuk kamu, guna memelihara kamu dalam peperanganmu; Maka hendaklah kamu bersyukur (kepada Allah) (Kemenag 2012).

Ada 2 hal yang menarik disini yaitu Allah SWT menyeru untuk melakukan proses produksi kemudian bersyukur atas apa yang dihasilkannya. Dimana setiap hal yang berhasil dilakukan (produksi) sudah sepatutnya kita bersyukur

Di surat lainnya yaitu pada surat Saba' (10-11) Allah juga melanjutkan kisah Nabi Daud namun menambahkan lagi bahwasanya manusia selain melakukan proses peoduksi harus dibarengi dengan melakukan amal saleh. Hal tersebut tertulis dalam surat sebagai berikut:

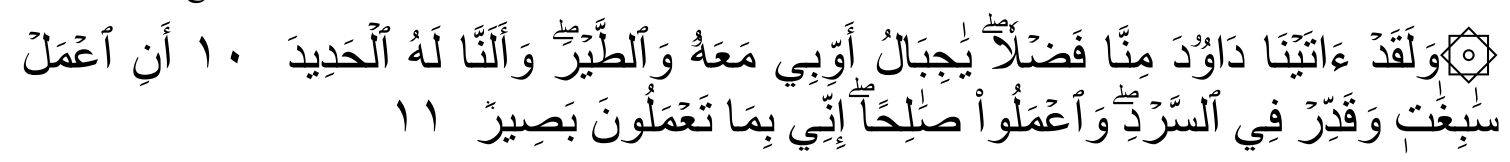

Terjemahnya:

Dan sesungguhnya telah Kami berikan kepada Daud kurnia dari Kami. (Kami berfirman): "Hai gunung-gunung dan burung-burung, bertasbihlah berulang-ulang bersama Daud", dan Kami telah melunakkan besi untuknya,

(yaitu) buatlah baju besi yang besar-besar dan ukurlah anyamannya; dan kerjakanlah amalan yang saleh. Sesungguhnya Aku melihat apa yang kamu kerjakan.

Adapun tindakan monopoli sangat ditentang oleh Allah SWT, sebagaimana tertulis dalam Al-Quran surat Al-syu'ara (183), sebagai berikut:

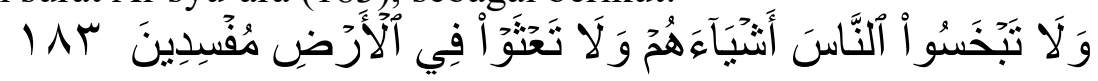

Terjemahnya: Dan janganlah kamu merugikan manusia pada hak-haknya dan janganlah kamu merajalela di muka bumi dengan membuat kerusakan;

Pesan dalam ayat tersebut agar manusia tidak melakukan tindakan yang merugikan manusia pada hak-haknya, kemudian Allah SWT menyerukan bahwa segala tindakan yang dilakukan di muka bumi agar tidak membuat kerusakan didalamnya. Namun apa yang kita lihat bagaimana serakahnya manusia dalam memenuhi kebutuhan ekonominya bahkan harus mengorbankan manusia lainnya dan juga lingkungan sebagai penyeimbang alam. Contoh kasusnya pada kasus Lapindo yang dipandang sebagai kegiatan produksi yang menyebabkan tidak hanya bencana alam, akan tetapi juga 


\section{AkMen}

menyebabkan bencana sosial (Novenanto 2010). (de Rosari 2007) menganggap kejadian tersebut sebagai kasus yang cukup rumit hingga membuat masyarakat sekitar membuat gugatan terhadap Lapindo.

Keseimbangan dalam kegiatan ekonomi adalah keniscayaan untuk mendapatkan kesejahteraan yang hakiki, baik hubungan antara manusia, lingkungan hingga hubungan dengan sang pencipta (Allah SWT). Konsep keseimbangan ini juga erat kaitannya dengan sikap jujur dalam menjalani aktivitas perdagangan. Al-Quran jauh sebelumnya juga telah mengingatkan kita mengenai hal ini sebagaimana tertulis di dalam surat AlAn'am (152) sebagai berikut:

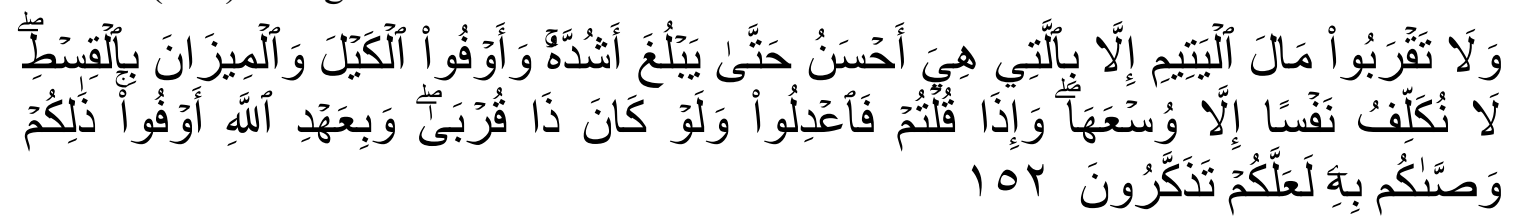

Terjemahnya:

Dan janganlah kamu dekati harta anak yatim, kecuali dengan cara yang lebih bermanfaat, hingga sampai ia dewasa. Dan sempurnakanlah takaran dan timbangan dengan adil. Kami tidak memikulkan beban kepada sesorang melainkan sekedar kesanggupannya. Dan apabila kamu berkata, maka hendaklah kamu berlaku adil, kendatipun ia adalah kerabat(mu), dan penuhilah janji Allah. Yang demikian itu diperintahkan Allah kepadamu agar kamu ingat.

Kemudian Allah SWT juga mengingatkan perihal yang sama dalam Al-Quran surat Al-Syu'ara (181-182) sebagai berikut:

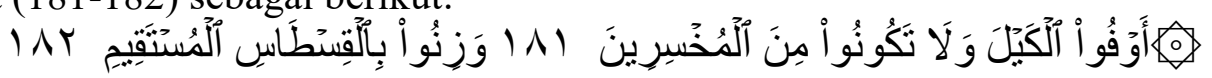

Terjemahnya: Sempurnakanlah takaran dan janganlah kamu termasuk orang-orang yang merugikan; dan timbanglah dengan timbangan yang lurus.

Keseimbangan juga erat kaitannya dengan keseimbangan dalam laporan keuangan, sebagaimana tertulis di dalam surat Al-Rahman (8) sebagai berikut:

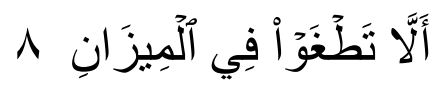

Terjemahnya: Supaya kamu jangan melampaui batas tentang neraca itu.

Kasih sayang Allah terhadap manusia juga disampaikan dalam surat Al-Isra (12) sebagai berikut:

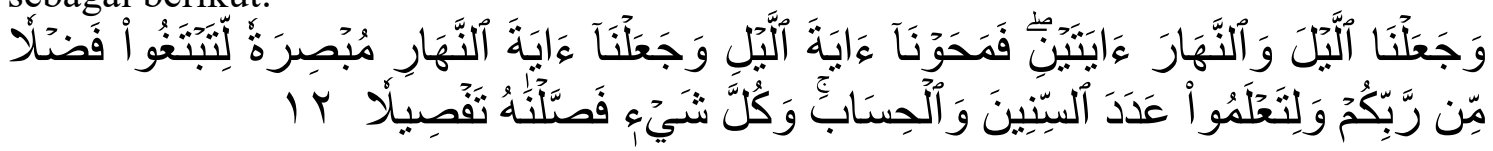

Terjemahnya:

Dan Kami jadikan malam dan siang sebagai dua tanda, lalu Kami hapuskan tanda malam dan Kami jadikan tanda siang itu terang, agar kamu mencari kurnia dari Tuhanmu, dan supaya kamu mengetahui bilangan tahun-tahun dan perhitungan. Dan segala sesuatu telah Kami terangkan dengan jelas. 


\section{AkMen}

Allah SWT telah memberikan kadar waktu dalam mencari nafkah sebagaimana yang tertulis pada ayat tersebut. Pada waktu siang yang terang Allah menyeru kita untuk mencari karunianya dengan bekerja sungguh-sungguh.

Kegiatan ekonomi yang dijalani sehari-hari tidak terlepad dari perdagangan. Oleh karena itu dalam perdagangan pun Allah SWT telah mengingatkan di dalam AlQuran. Sekaligus sebagai ayat yang terpanjang didalam Al-Quran menjelaskan mengenai perdagangan tersebut, yaitu pada surat Al-Baqarah (282) sebagai berikut:

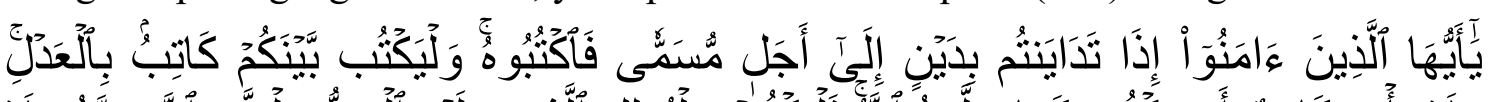

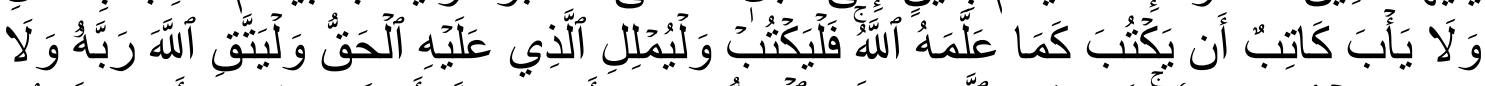

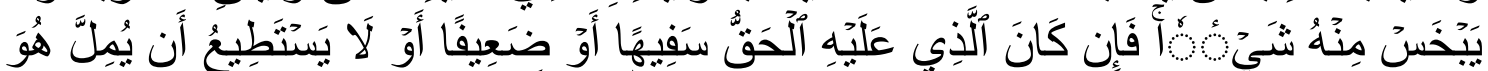

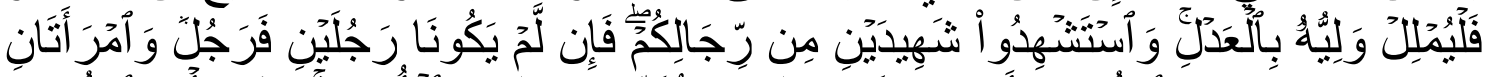

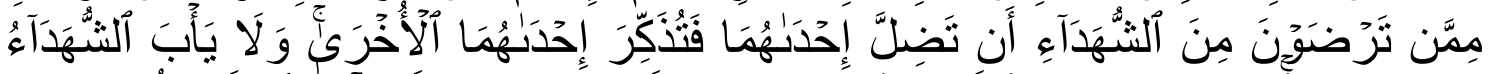

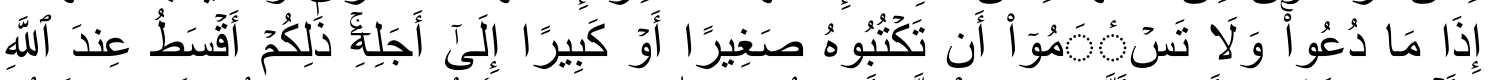

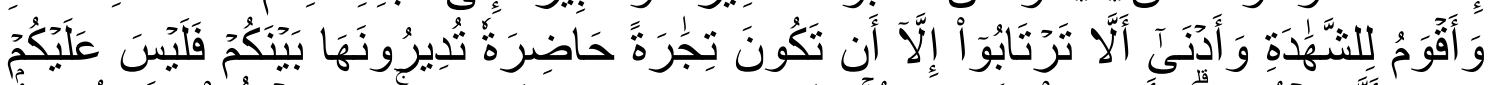

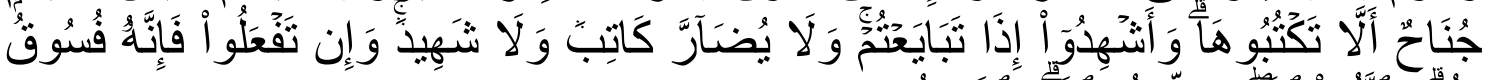

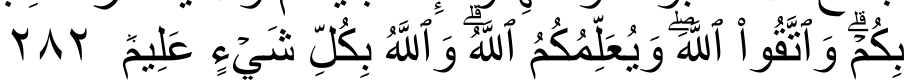

Terjemahnya:

Hai orang-orang yang beriman, apabila kamu bermu'amalah tidak secara tunai untuk waktu yang ditentukan, hendaklah kamu menuliskannya. Dan hendaklah seorang penulis di antara kamu menuliskannya dengan benar. Dan janganlah penulis enggan menuliskannya sebagaimana Allah mengajarkannya, meka hendaklah ia menulis, dan hendaklah orang yang berhutang itu mengimlakkan (apa yang akan ditulis itu), dan hendaklah ia bertakwa kepada Allah Tuhannya, dan janganlah ia mengurangi sedikitpun daripada hutangnya. Jika yang berhutang itu orang yang lemah akalnya atau lemah (keadaannya) atau dia sendiri tidak mampu mengimlakkan, maka hendaklah walinya mengimlakkan dengan jujur. Dan persaksikanlah dengan dua orang saksi dari orang-orang lelaki (di antaramu). Jika tak ada dua oang lelaki, maka (boleh) seorang lelaki dan dua orang perempuan dari saksi-saksi yang kamu ridhai, supaya jika seorang lupa maka yang seorang mengingatkannya. Janganlah saksi-saksi itu enggan (memberi keterangan) apabila mereka dipanggil; dan janganlah kamu jemu menulis hutang itu, baik kecil maupun besar sampai batas waktu membayarnya. Yang demikian itu, lebih adil di sisi Allah dan lebih menguatkan persaksian dan lebih dekat kepada tidak (menimbulkan) keraguanmu. (Tulislah mu'amalahmu itu), kecuali jika mu'amalah itu perdagangan tunai yang kamu jalankan di antara kamu, maka tidak ada dosa bagi kamu, (jika) kamu tidak menulisnya. Dan persaksikanlah apabila kamu berjual beli; dan janganlah penulis dan saksi saling sulit menyulitkan. Jika kamu lakukan (yang demikian), maka sesungguhnya hal itu adalah suatu kefasikan pada 
dirimu. Dan bertakwalah kepada Allah; Allah mengajarmu; dan Allah Maha Mengetahui segala sesuatu.

Sebagai bumbu pelengkap dalam mengarungi samudera ekonomi dalam tatanan ajaran Islam, maka ada aturan khusus didalamnya yang tidak boleh dilakukan dalam perdagangan maupun transaksi lainnya, yaitu transaksi yang mengandung unsur "riba". Allah SWT telah mengingatkan hal tersebut dalam surat Al-Baqarah (275) sebagai berikut:

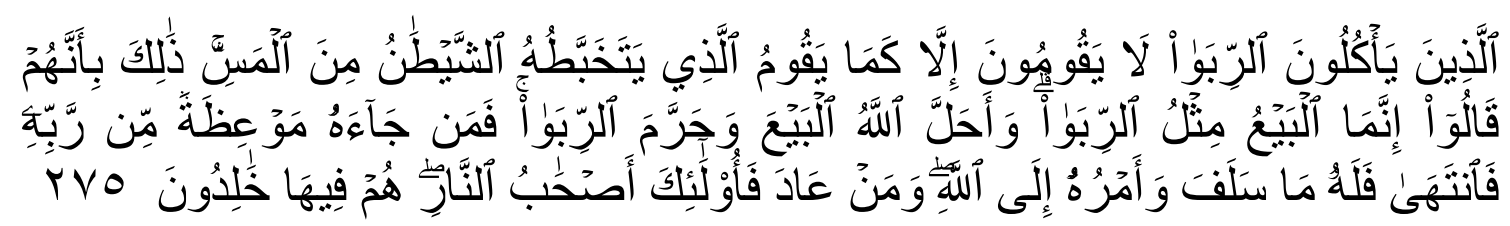

Terjemahnya:

Orang-orang yang makan (mengambil) riba tidak dapat berdiri melainkan seperti berdirinya orang yang kemasukan syaitan lantaran (tekanan) penyakit gila. Keadaan mereka yang demikian itu, adalah disebabkan mereka berkata (berpendapat), sesungguhnya jual beli itu sama dengan riba, padahal Allah telah menghalalkan jual beli dan mengharamkan riba. Orang-orang yang telah sampai kepadanya larangan dari Tuhannya, lalu terus berhenti (dari mengambil riba), maka baginya apa yang telah diambilnya dahulu (sebelum datang larangan); dan urusannya (terserah) kepada Allah. Orang yang kembali (mengambil riba), maka orang itu adalah penghuni-penghuni neraka; mereka kekal di dalamnya.

Riba dalam hal ini terdiri dari 2 macam, yaitu nasiah dan fadhl. Riba nasiah yaitu pembayaran lebih yang disyaratkan oleh orang yang memberikan pinjaman, sedangkan riba fadhl adalah penukaran suatu barang dengan barang yang sejenis, tetapi dengan syarat yang lebih banyak jumlahnya karena orang yang menukarkan memberikan syarat yang demikian, misalnya menukarkan emas dengan emas, padi dengan padi dan lainnya yang sifatnya sejenis.

Begitupun yang berkenaan dengan transaksi yang terdapat kondisi utang piutang didalamnya sebagaimana tertulis di dalam Al-Quran surat Al-Baqarah (280) sebagai berikut:

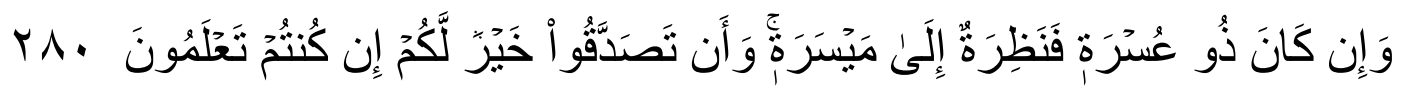

Terjemahnya: 
Dan jika (orang yang berhutang itu) dalam kesukaran, maka berilah tangguh sampai dia berkelapangan. Dan menyedekahkan (sebagian atau semua utang) itu, lebih baik bagimu, jika kamu mengetahui.

Jika melihat implementasi dan permasalahan utang piutang dalam kegiatan ekonomi konvensional saat ini letaknya ada pada pemberian bunga dalam transaksi. Terlebih lagi apabila tempo yang seharusnya diselesaikan oleh orang yang meminjam telah lewat, maka akan dikenakan denda atas pokok pinjamannya. Dalam surat AlBaqarah (280) telah tertulis dengan jelas mengenai pemberian kelapangan tempo untuk melunasi pinjaman ditambah lagi dengan menyedekahkan sebagian atau semua utang akan lebih baik lagi terlepas dari kewajiban yang berhutang. Artinya kita harus melihat kondisi dan memberikan kelapangan dalam transaksi utang piutang tersebut.

Inti daripada kegiatan ekonomi dalam ajaran Islam adalah Muamalah sebagaimana yang dijelaskan dalam Al-Quran surat Al-Baqarah (282). Beberapa pilar penting dalam Muamalah diantaranya: Pasar serta Dinar dan Dirham sebagai alat transaksi/harta. Dalam Muamalah juga menekankan kebebasan bagi masyarakat dalam bertransaksi berdasarkan ketentuan didalam Al-Quran sebagai tuntunan. Selain itu elemen yang harus dijauhi dalam muamalah itu sendiri adalah transaksi Riba.

Al-Quran dan semangat ekonomi yang berketuhanan memerintahkan manusia untuk percaya dan terlibat dalam perdagangan dalam semangat niat baik, sebagaimana di dalam surat An Nisa' ayat 29 sebagai berikut:

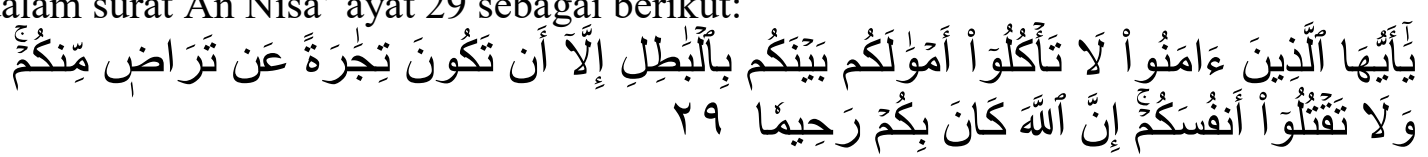

Terjemahnya:

Hai orang-orang yang beriman, janganlah kamu saling memakan harta sesamamu dengan jalan yang batil, kecuali dengan jalan perniagaan yang berlaku dengan suka sama-suka di antara kamu. Dan janganlah kamu membunuh dirimu; sesungguhnya Allah adalah Maha Penyayang kepadamu.

Tidak ada sebutan untuk uang kertas ataupun uang fiat di dalam Al-Quran. Harta maupun transaksi dilakukan dengan menggunakan emas dan perak. Harta terkait emas dan perak tertulis dalam Al-Quran pada surat Al-'Imran (14) sebagai berikut:

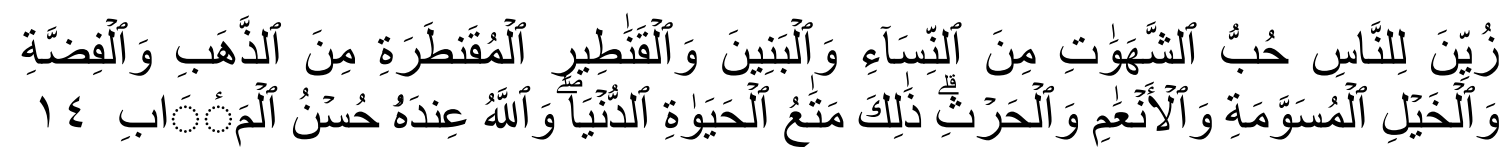

Terjemahnya:

Dijadikan indah pada (pandangan) manusia kecintaan kepada apa-apa yang diingini, yaitu: wanita-wanita, anak-anak, harta yang banyak dari jenis emas, perak, kuda pilihan, binatang-binatang ternak dan sawah ladang. Itulah kesenangan hidup di dunia, dan di sisi Allah-lah tempat kembali yang baik (surga).

Dalam ayat tersebut dapat kita pahami bahwasanya emas dan perak adalah termasuk golongan harta. Namun manusia harus sadar bahwa itu semua adalah milik 
Allah dan sesungguhnya kecintaan berlebih kepada harta akan membuat manusia tersesat dalam kehidupan dunia yang tidak abadi.

(Lidyana 2015) mengemukakan bahwasanya terdapat perbedaan diantara sistem ekonomi kapitalis, sosialis, dan Islam yang dijabarkan pada tabel sebagai berikut:

Tabel 3. Sistem Ekonomi Kapitalis, Sosialis, dan Ekonomi Islam (Lidyana 2015).

\begin{tabular}{|l|l|l|l|}
\hline \multicolumn{1}{|c|}{ Sumber Kekayaan } & \multicolumn{1}{|c|}{ Kapitalis } & \multicolumn{1}{c|}{ Sosialis } & \multicolumn{1}{c|}{ Islam } \\
\hline Sumber Kekayaan & $\begin{array}{l}\text { Sumber Kekayaan Sangat } \\
\text { Langka }\end{array}$ & $\begin{array}{l}\text { Sumber Kekayaan Sangat } \\
\text { Langka }\end{array}$ & $\begin{array}{l}\text { Sumber kekayaan bersumber } \\
\text { dari Allah SWT }\end{array}$ \\
\hline Kepemilikan & $\begin{array}{l}\text { Bebas memiliki semua } \\
\text { kekayaan yang diperolehnya }\end{array}$ & $\begin{array}{l}\text { Sumber kekayaan diperoleh } \\
\text { dari pemberdayaan tenaga } \\
\text { kerja (buruh) }\end{array}$ & Bersumber dari Allah SWT \\
\hline Tujuan/Gaya Hidup & Kepuasan Pribadi & $\begin{array}{l}\text { Kesetaraan penghasilan dari } \\
\text { kaum buruh }\end{array}$ & $\begin{array}{l}\text { Untuk mencapai kebaikan } \\
\text { dunia dan akhirat }\end{array}$ \\
\hline
\end{tabular}

Tabel diatas memperlihatkan perbandingan bahwasanya baik sumber kekayaan, kepemilikan dan tujuan hidup semata-mata adalah mencari kebaikan di sisi Allah SWT, karena materi yang dimiliki oleh setiap manusia, bersumber dan akan kembali kepada Allah SWT.

Ayat-ayat di dalam Al-Quran telah menjelaskan kepada kita sebagai khalifah di muka bumi, bahwasanya manusia harus menjaga dan melestarikan segala nikmat yang telah diberikan oleh Allah dimuka bumi. keserakahan dan sikap monopoli akan mengakibatkan kerusakan dimuka bumi sebagaimana firman Allah di dalam surat AlBaqarah (30) sebagai berikut:

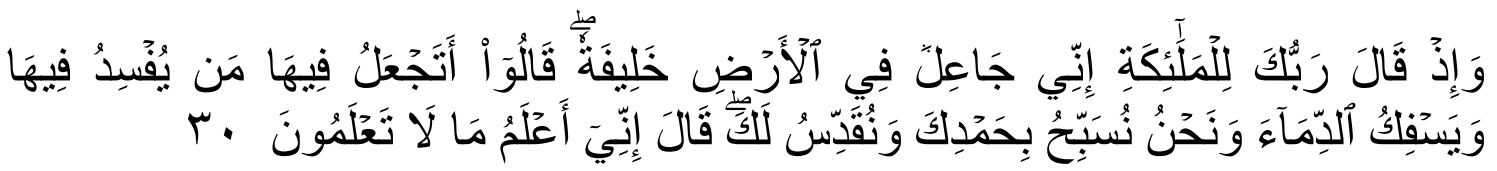

Terjemahnya:

Ingatlah ketika Tuhanmu berfirman kepada para Malaikat: "Sesungguhnya Aku hendak menjadikan seorang khalifah di muka bumi". Mereka berkata: "Mengapa Engkau hendak menjadikan (khalifah) di bumi itu orang yang akan membuat kerusakan padanya dan menumpahkan darah, padahal kami senantiasa bertasbih dengan memuji Engkau dan mensucikan Engkau?" Tuhan berfirman: "Sesungguhnya Aku mengetahui apa yang tidak kamu ketahui".

\section{KESIMPULAN}

1. Ekonomi Islam bukanlah tradisi intelektual kuno, akan tetapi ekonomi Islam merupakan gerakan modern yang menegaskan bahwa tradisi hukum dan organisasi Islam memberikan model pertumbuhan ekonomi yang lebih adil dan merata daripada sistem saingan kapitalisme dan sosialisme Barat. Kapitalisme Barat, konon, telah mampu memberikan kemajuan yang dinamis dan tingkatan ekspansif yang cukup besar, tetapi pencapaiannya diikuti dengan ketidaksetaraan dan eksploitasi pekerja oleh kapitalis.

2. Sebaliknya, ekonomi Islam menolak hal tersebut dengan memberikan kesetaraan hubungan antara pembeli dan pedagang sebagaimana yang diatur di dalam AlQuran. 
3. Kesenjangan dan perbedaan tujuan dalam ekonomi kapitalis-sosialis dengan ajaran ekonomi dalam Islam adalah tujuannya, yaitu mencari keridhaan dari Allah SWT dan kebaikan dunia dan akhirat.

\section{SARAN}

Penelitian ini masih dalam taraf kajian analisis deskriptif terkait teori ekonomi kapitalis-sosialis dengan melihat kaitannya dengan ketentuan dalam Al-Quran. Lebih lanjut penelitian lainnya dapat melihat dampak perekonomian lebih mendalam ditengah masyarakat ataupun dampak signifikannya terhadap kesejahteraan masyarakat.

\section{UCAPAN TERIMA KASIH}

Penulis mengucapkan terima kasih kepada STIE NOBEL Makassar yang telah memberikan kesempatan untuk penerbitan karya ilmiah ini. Terima kasih pula kepada Orang tua yang senantiasa memberikan dorongan untuk terus menulis karya ilmiah dan belajar. Serta keluarga (Istri dan Anak) yang senantiasa memberikan semangat dalam menambah khasanah pengetahuan. Dan kepada Universitas Muhammadiyah Makassar, yang telah memfasilitasi setiap usaha penulis dalam penerbitan karya Ilmiah.

\section{DAFTAR PUSTAKA}

BPS. “Tingkat Pengangguran.” Badan Pusat Statistik. https://www.bps.go.id/pressrelease/2020/05/05/1672/februari-2020--tingkatpengangguran-terbuka--tpt--sebesar-4-99-persen.html.

Buchanan, James M. 1968. 5 The Demand and Supply of Public Goods. Rand McNally Chicago.

Clarke, Abdassamad. Ekonomi Profetik. 1st ed. ed. Zaim Saidi. Indonesia: Pustaka Adina.

Durvasula, Srinivas, and Steven Lysonski. 2010. "Money, Money, Money-How Do Attitudes toward Money Impact Vanity and Materialism?-The Case of Young Chinese Consumers." Journal of Consumer Marketing.

Friedman, Milton. 1962. "With the Assistance of Rose D. Friedman.(1962). Capitalism and Freedom."

Goldberg, Herb, and Robert T Lewis. 1978. "Money Madness: The Psychology of Saving." Spending, Loving, and Hating Money, New York: New American Library: p64.

Hefner, Robert W. 2006. “Islamic Economics and Global Capitalism.” Society 44(1): 16-22.

Kemenag, R I. 2012. “Al-Qur’an Dan Terjemahnya.” Jakarta: PT Sinergi Pustaka Indonesia.

Lidyana, Novita. 2015. "Perbandingan Ekonomi Konvensional Dan Ekonomi Islam." Iqtishodiyah: Jurnal Ekonomi dan Bisnis Islam 1(1): 67-80.

Mason, Edward S. 1937. "Monopoly in Law and Economics." The Yale Law Journal 47(1): 3449.

Mayer, Carl. 1975. “Max Weber's Interpretation of Karl Marx.” Social Research: 701-19.

Novenanto, Anton. 2010. “Melihat Kasus Lapindo Sebagai Bencana Sosial.” Masyarakat, 
Kebudayaan, DanPolitik 23(1): 63-75.

Pack, Spencer J. 1991. “Capitalism as a Moral System.” Books.

Pryor, Frederic L. 2010. “Capitalism and Freedom?” Economic systems 34(1): 91-104.

Quigley, Carroll. 1966. Tragedy \& Hope. Macmillan New York.

Richins, Marsha L, and Scott Dawson. 1992. "A Consumer Values Orientation for Materialism and Its Measurement: Scale Development and Validation." Journal of consumer research 19(3): 303-16.

de Rosari, Aloysius Soni B L. 2007. Banjir Lumpur Banjir Janji: Gugatan Masyarakat Dalam Kasus Lapindo. Penerbit Buku Kompas.

Shaykh Umar Ibrahim Vadillo. 2016. Membongkar Sihir Negara. ed. zaim saidi. Indonesia: Pustaka Adina.

Vaughn, Karen I. 1989. "Invisible Hand.” In The Invisible Hand, Springer, 168-72.

Youn, Seounmi, and Kenneth O Doyle. 1999. "Toward a Cross-Disciplinary Dialogue About the Meanings of Money." Advances in Consumer Research 26(1). 